\title{
Analysis of the Clinical Volunteer Complaint Relation with Dangerous Substances in Cosmetic Formula Used
}

\author{
Titik Taufikurohmah*, Siti Tjahjani, I \\ Gusti Made Sanjaya, Andika Pramudya \\ Wardana \\ Department of Chemistry \\ Universitas Negeri Surabaya \\ Surabaya, Indonesia \\ titiktaufikurohmah@unesa.ac.id
}

\author{
Hans Lumintang \\ Department of Dermatology and Sex \\ Universitas Widya Mandala \\ Surabaya, Indonesia
}

\author{
Tjandrakira \\ Department of Biology \\ Universitas Negeri Surabaya \\ Surabaya, Indonesia
}

\author{
Afaf Baktir \\ Department of Chemistry \\ Universitas Airlangga Surabaya \\ Surabaya, Indonesia
}

\author{
Achmad Syahrani \\ Department of Pharmacy \\ Universitas Airlangga Surabaya \\ Surabaya, Indonesia
}

Adi Soeprijanto

Department of Electrical Engineering

Institut Teknologi Sepuluh Nopember

Surabaya, Indonesia

\begin{abstract}
Dangerous substances in cosmetics have been widely known especially mercury face whitening. Socialization of the impact has also been made by NA-DFC (The National Agency of Drug and Food Control. However, the circulation of cosmetics contain contains mercury still exist on the community society. It needs an effort to convince the society about the dangers of mercury, by showing directly the users' complaints data about cosmetics that contains mercury on it. The research got accurate data from those cosmetic user as volunteer. This research is intended to give accurate information on the impact of the use of cosmetics containing that contain mercury on the face through the volunteers' complaints in medical records. Research data in the form of volunteer medical record data and the data content of mercury in cosmetics are used. The result showed there are strong correlation between volunteer complaints i.e., spot, acne and blackheads with mercury that contains in cosmetics formula used. It can be concluded that mercury in cosmetics causes dangerous effects including spot, acne and blackheads. It is hoped that this research will bring cosmetics users not to use mercury cosmetics although the result is nice in the beginning.
\end{abstract}

Keywords- cosmetics, mercury, black spot, acne, blackheads.

\section{INTRODUCTION}

The use of whitening in cosmetics is already common nowadays, even dangerous materials. Dangerous whitening material in cosmetics include mercury [1], hydroquinone [2], retinoic acid [3] and alpha hydroxy acid (AHA) (KEUN, HEE and JIN 2010). This is inseparable from misleading advertising that is often shown in the society that beautiful is identical to whites. This also triggers the use of harmful whitening substances on cosmetic formulas [4]. This phenomenon occurred not only in Indonesia but also in Malaysia, Singapore, Thailand, India, Korea and other countries [5] [6].

In Indonesia, the circulation of cosmetics containing mercury is caused by a less assertive regulation which is the use of it is prohibited but there is a regulation that permits the limitation of that, the limits is $70 \mathrm{ppm}$ [7]. This is strongly opposed by environmental activists who ratified a law on the threshold of mercury in the environment from the FDA, that limit threshold about 10 ppm [8]. The threshold is very much different even the threshold limit in cosmetics is much higher than the threshold limit in the environment. This needs to be thought together because the impact of mercury is very detrimental to health.

During this time the information of the addicted effects and discontinuation of use during pregnancy does not give a strong warning to the society [9] The use of mercury in cosmetics is increasing from time to time. Even though they already know, the termination of this cosmetic is very difficult and still circulating in the wider community. It takes even more effort to educate the public about the dangers of cosmetics containing mercury [10][11]. This clinical research activity is intended to inform the public of the real impacts of cosmetic-containing mercury can cause very bad medical records for the volunteers and that should be avoided [12][13].

Mercury in cosmetics has caused many metabolic disorders in a variety of important human tissues. In addition to damage to the skin, also damage to the kidneys, lung damage, heart damage, reproductive organ damage, brain [13] and nerve (Luiza et al 2016.) damage due to accumulate in the brain (Pereira et al 2016.) and liver damage [7][14]. The damage caused by the use of mercury in cosmetics is not only limited to tissue but also to the cellular level that causes cell mutation and cancer [15].

Mercury inflicts directly on Melanocyte cells where the presence of mercury initially suppresses this cell's work and further disrupts the cell metabolic system [16][17]. Indeed melanocyte cells are in charge of keeping the skin surface from damage caused by sunburn, especially Ultra Violet rays by releasing melanin as a skin cells protector [18]. 
This research is intended to express the complaints of cosmetic users containing mercury as a form of awareness and increased public awareness of the existence of this cosmetic in order not to become next victims of cosmetics containing mercury.

\section{MATERIALS AND METHOD}

This research involves cosmetic user as a volunteer with the age limit of 15 years and over, beside checking volunteers' skin health they brought their cosmetics sample which will be analyzed it contains mercury or not through Chemical Laboratory with Voltammetry Striping Ion method. Volunteers also receive sufficient explanation regarding this research and sign an agreement or inform consensus agreement and also they have the freedom to cancel if they change their mind later. As well as the confidentiality volunteers' identity and the result of the research will be the responsibility of the researcher who will use them as scientific data to be published in accordance with the agreed ethics and with the approval of the Research Ethics Commission Volunteer's medical conditions will be linked to cosmetic formulas that have been used previously. The long use of cosmetics and the formula has a profound effect on the medical condition of volunteer's facial skin.

\section{RESULTS AND DISCUSSION}

Volunteers are 45 people with the results of cosmetic analysis used primarily mercury content analysis, obtained data as presented in table 1. With medical complaints recorded briefly show the main complaints of each volunteer.

TABLE I. VOLUNTEERS’ MEDICAL RECAP

\begin{tabular}{|c|c|c|c|}
\hline No & Complaints & Long wear & $\begin{array}{l}\text { Mercury } \\
(+/-)\end{array}$ \\
\hline 1 & No complaints & 3 months & - \\
\hline 2 & No complaints & 2 months & - \\
\hline 3 & Pimply & 3 years & + \\
\hline 4 & $\begin{array}{ll}\begin{array}{l}\text { Black } \\
\text { appears }\end{array} & \text { spot } \\
\end{array}$ & 4 months & + \\
\hline 5 & No complaints & 1 month & - \\
\hline 6 & $\begin{array}{lll}\begin{array}{l}\text { Face } \\
\text { clean }\end{array} & \text { still not } \\
\end{array}$ & 1 year & + \\
\hline 7 & No complaints & 6 years & - \\
\hline 8 & Blackish skin & 7 years & + \\
\hline 9 & No complaints & 4 years & - \\
\hline 10 & Pimply & 6 months & + \\
\hline 11 & Blackish Face & 6 months & + \\
\hline 12 & Pimply face & 7 years & + \\
\hline 13 & Blackish skin & 7 years & + \\
\hline 14 & $\begin{array}{l}\text { The skin is } \\
\text { getting dry }\end{array}$ & 2 months & + \\
\hline 15 & Acne appears & 8 months & + \\
\hline 16 & Oily, blackheads & 2 years & + \\
\hline 17 & Dry skin & 1 year & + \\
\hline 18 & Still have flecks & 6 months & + \\
\hline 19 & No complaints & 1 year & - \\
\hline 20 & Dull, oily & - & + \\
\hline
\end{tabular}

\begin{tabular}{|l|l|l|c|}
\hline 21 & No complaints & 3 months & + \\
\hline 22 & Small acne & 1 month & + \\
\hline 23 & Pimples & 1 year & + \\
\hline 24 & $\begin{array}{l}\text { Flecks appear if it } \\
\text { stop }\end{array}$ & 5 years & + \\
\hline 25 & Pimply & 2 years & + \\
\hline 26 & Pimply & 3 months & + \\
\hline 27 & Reddish Face & 3 months & + \\
\hline 28 & Pimply & 1 year & + \\
\hline 29 & Black face & 5 years & + \\
\hline 30 & Brighter skin & 1 month & + \\
\hline 31 & Fleck & 2 years & + \\
\hline 32 & $\begin{array}{l}\text { Reddish } \\
\text { Flecks }\end{array}$ & 2 months & + \\
\hline 33 & No complaints & 1 year & + \\
\hline 34 & Black flecks & - & + \\
\hline 35 & Pimply & 3 months & + \\
\hline 36 & Dull face & 1 month & + \\
\hline 37 & $\begin{array}{l}\text { Little flecks on } \\
\text { the cheek }\end{array}$ & - & + \\
\hline 38 & Thin and oily skin & 3 years & + \\
\hline 39 & Pimply & 2 years & + \\
\hline 40 & $\begin{array}{l}\text { Blackheads are } \\
\text { increased }\end{array}$ & 1 year & + \\
\hline 41 & Dry skin & 6 months & + \\
\hline 42 & No change & 2 years & + \\
\hline 43 & No complaints & 6 months & + \\
\hline 44 & No complaints & 2 months & + \\
\hline 45 & $\begin{array}{l}\text { pimples, } \\
\text { blackheads, oily }\end{array}$ & 2 months & + \\
\hline
\end{tabular}

Data from Table 1. Shows that from 45 creams are used by volunteers 39 of them are positive containing mercury. This indicates an increase in the ratio of cosmetics containing mercury in the society this statement accorded to 2012 research data that state 5 of 6 cosmetics that circulate widely in the community contain mercury [19]. This means that increase from $83.3 \%$ to $86.6 \%$ over the last 5 years. People are not afraid of the dangers of mercury that can cause neurological disorders and important organ damage [20].

Complaints caused by the use of cosmetics containing mercury is the appearance of black spots, acne, blackheads, oily skin, dry skin, skin redness and dull skin. However, it should be noted that some people have not experienced a complaint even after 1 year of using, as well as volunteers who have 2 months, 3 months and 6 months also have no complaints.

Even before the complaints arise in general they are very satisfied with the results because the skin become smooth, white, soft without acne and black spots. This very satisfying condition generally makes the users very unconvinced of the bad impact in the future. In a short time their skin turned into their wishes and it is very satisfying Of the 39 volunteers who positively uses cosmetics contain mercury only 3 people or $7.6 \%$ that do not have complaints, $92.4 \%$ complain of pimples, black spots and blackheads accompanied by oily skin. So that's why public should be alert when found the complaint after using cosmetics. 
Although the skin turned white in a short of time do not satisfied with that, pay attention to the skin's health.

Generally, volunteers who use cosmetics which contain no mercury, there are no complaints. In General, skin's health is quite good although it's not white. It needs to be appreciated for minority groups (13.4\%) who still thinking about their health beside the phenomenal white skin nowadays.

\section{CONCLUSION}

From the results that obtained in this research we can conclude that :

1) Common complaints of cosmetic users contain mercury i.e. the skin becomes pimply, black spot, oily, reddish, dry and dull. Although everyone has different times for complaints resulting from the use of these mercury-containing cosmetics.

2) Common stages for this mercury-containing cosmetics user, i.e. in the early use of cosmetics, in general, are very satisfied with the results which is vanished acne, dead skin and dull disappear as well as stains or skin with uneven color will be clean white. Irregular use and discontinuation will result in complaints starting from black spots, acne, redness, oily skin, dry and dull skin.

\section{ACKNOWLEDGMENT}

Thanks to Ministry of Research, Technology, and Higher Education of The Republic of Indonesia through the PUSN scheme in year 2018 and UNESA's LPPM has disbursed funds from Ministry of Research, Technology, and Higher Education of The Republic of Indonesia.

\section{REFERENCES}

[1] Karnani, Aneel. "Doing Well by Doing Good - Case Study: 'Fair \& Lovely' Whitening Cream.” 2007. Strategic Management Journal 28(13): 1351-57

[2] Haddad, Alessandra Lima et al. "A Clinical, Prospective, Randomized, Double-Blind Trial Comparing Skin Whitening Complex with Hydroquinone vs. Placebo in the Treatment of Melasma." 2003. International Journal of Dermatology 42(2): 15356.

[3] Suhartini, Siti, G. Citraningtyas, and Program Studi Farmasi. "Analisis Asam Retinoat Pada Kosmetik Krim Pemutih Yang Beredar Di Pasaran Kota Manado.” 2013. 2(1): 1-8.

[4] Taufikurohmah, T. et al. "Mercury Exposure Effects to Skin Tissue of Mus Muscullus at Fibroblasts Cell Proliferation and Collagen Quantity." 2013. Research Journal of Pharmaceutical, Biological and Chemical Sciences 4(4)

[5] Fari, N Rodríguez et al. "Mercury and Selenium Binding Biomolecules in Terrestrial Mammals ( Cervus Elaphus and Sus Scrofa ) from a 2016. Mercury Exposed Area." 1022: 159-66
[6] Kim, Tagon et al. 2011. "Nelumbo Nucifera Extracts as Whitening and Anti-Wrinkle Cosmetic Agent." 2011. Korean Journal of Chemical Engineering 28(2): 424-27

[7] Bourdineaud, Jean-paul, Muriel Laclau, Régine Maury-brachet, and Patrice Gonzalez. "Effects of Methylmercury Contained in a Diet Mimicking the Wayana Amerindians Contamination through Fish Consumption: Mercury Accumulation , Metallothionein Induction , Gene Expression Variations, and Role of the Chemokine CCL2." 2012 (June): $7710-38$

[8] Administration, U S Food and Drug. "Considering Whether an FDARegulated Product Involves the Application of Nanotechnology." 2011. 2011-6-14)[2011-08-15]. http://www. fda. gov/RegulatoryInformation/Guidances/ucm257698. htm\# ftnl (June): $1-14$.

[9] Pallocca, Giorgia et al. "Changes in miRNA Expression Profiling during Neuronal Differentiation and Methyl Mercury-Induced Toxicity in Human in Vitro Models." : 2014. 443-63

[10] García-sevillano, M A, T García-barrera, F Navarro, and J L Gómezariza. "Analytica Chimica Acta Absolute Quanti Fi Cation of Superoxide Dismutase in Cytosol and Mitochondria of Mice Hepatic Cells Exposed to Mercury by a Novel Metallomic Approach." 2014. $\begin{array}{llll}\text { Analytica } & \text { Chimica } & \text { Acta } & \text { 842: }\end{array}$ http://dx.doi.org/10.1016/j.aca.2014.07.014

[11] Pereira, Patrícia et al. "Science of the Total Environment Fish Eyes and Brain as Primary Targets for Mercury Accumulation - A New Insight on Environmental Risk Assessment." 2014. Science of the Total Environment, The 494-495: 290-98. http://dx.doi.org/10.1016/j.scitotenv.2014.07.008

[12] Pallocca, Giorgia et al. "Changes in miRNA Expression Profiling during Neuronal Differentiation and Methyl Mercury-Induced Toxicity in Human in Vitro Models." :2014. 443-63.

[13] Rooney, James P K. "The Retention Time of Inorganic Mercury in the Brain - A Systematic Review of the Evidence." 2014. Toxicology and Applied Pharmacology 274(3): 425-35. http://dx.doi.org/10.1016/j.taap.2013.12.011

[14] T. Taufikurohmah, Igusti Made Sanjaya, Afaf Baktir, and Achmad Syahrani. 2016. "HISTOCHEMICAL CHANGES LIVER AND KIDNEY OF MICE EXPOSED TO MERCURY AND RECOVERY WITH NANOGOLD." 11(1): 80-91

[15] Gill, Randall et al. "Docosahexaenoic Acid Counteracts Attenuation of CD95-Induced Cell Death by Inorganic Mercury." 2015. Toxicology and Applied Pharmacology 282(1): 61-67. http://dx.doi.org/10.1016/j.taap.2014.11.005.

[16] Jin, Li-hua, and Chang-soo Han. "Sensors and Actuators B : Chemical Eco-Friendly Colorimetric Detection of Mercury ( II ) Ions Using Label-Free Anisotropic Nanogolds in Ascorbic Acid Solution." 2014. Sensors \& Actuators: B. Chemical 195: 239-45. http://dx.doi.org/10.1016/j.snb.2014.01.020.

[17] P. Imam Budi et al. "MELANOCYTES SYSTEM , 2008.

[18] Hoshino, Tatsuya et al. "Suppression of Melanin Production by Expression of HSP70 * ๑." 2010. 285(17): 13254-63

[19] Taufikurohmah,Titik \& Setiarso, Pirim." Analisis kandungan merkuri pada kosmetik yang beredar di klinik Kecantikan Kota Surabaya". 2012. Prociding Nasional Conference, Chemistry Department Universitas Negeri Surabaya, U-Press

[20] Luiza, Ana et al. "NeuroToxicology Full Length Article Neurotoxic Impact of Mercury on the Central Nervous System Evaluated by Neuropsychological Tests and on the Autonomic Nervous System Evaluated by Dynamic Pupillometry.” 2015 Neurotoxicology (2015). http://dx.doi.org/10.1016/j.neuro.2016.04.010. 